\title{
PENGARUH PENGEMBANGAN KARIR \\ TERHADAP KINERJA PEGAWAI \\ (Studi pada CV. Lima Saudara Mandiri Bandar Lampung)
}

\author{
Oleh : \\ Suryani, S.Sos., MM. \\ Fajar Mutia Suri, S.E., MM. \\ Jurusan Administrasi Niaga, Universitas Tulang Bawang - Lampung \\ e-Mail : suryani_mr@yahoo.com
}

\begin{abstract}
The study aims to explain the effect of career development on employee performance. The research method used was an explanatory research method using questionnaires as a data collection tool distributed to 29 employees of CV. Lima Saudara Mandiri Bandar Lampung. Data analysis in this study uses descriptive analysis and multiple linear regression analysis. The results showed the regression line as follows: The results of data processing obtained that the results of the linear regression coefficient $Y=16,375+0,200 X$. The results of testing the hypothesis by " $t$ " test, with tcount > ttable (2.039> 1.671) then Ho is rejected and Ha is accepted, so it can be concluded that career development has an effect on employee performance.
\end{abstract}

Keywords: career development, employee performance.

\begin{abstract}
ABSTRAK
Penelitian ini bertujuan untuk menjelaskan pengaruh pengembangan karir terhadap kinerja karyawan. Metode penelitian yang digunakan adalah metode penelitian eksplanatori dengan menggunakan kuesioner sebagai alat pengumpul data yang disebarkan kepada 29 karyawan CV. Lima Saudara Mandiri Bandar Lampung. Analisis data dalam penelitian ini menggunakan analisis deskriptif dan analisis regresi linier berganda. Hasil penelitian menunjukkan garis regresi sebagai berikut: Hasil pengolahan data diperoleh hasil koefisien regresi linier $\mathrm{Y}=$ $16,375+0,200 \mathrm{X}$. Hasil pengujian hipotesis dengan uji “ $\mathrm{t}$ ”, dengan thitung> ttabel $(2,039>$ 1,671) maka Ho ditolak dan Ha diterima, sehingga dapat disimpulkan bahwa pengembangan karir berpengaruh terhadap kinerja pegawai.
\end{abstract}

Kata kunci: pengembangan karir, kinerja pegawai. 


\section{PENDAHULUAN}

Setiap perusahaan yang didirikan memiliki tujuan komersial maupun sosial. Untuk mencapai tujuan-tujuan tersebut diperlukan kinerja yang baik dari para pegawainya. Keberhasilan suatu perusahaan ditentukan dari kinerja para pegawai yang tergabung dalam manajemen perusahaan tersebut, mulai dari pengelolaan sumber daya manusia sampai proses pelaksanaan pekerjaan. Untuk itu perusahaan harus memberdayakan para pegawainya dengan sebaik mungkin. Manajemen kinerja tidak hanya memberi manfaat kepada perusahaan saja tetapi juga kepada individu dan manajer. Perusahaan harus menyesuaikan tujuan perusahaan dengan tujuan tim dan individu, meningkatkan komitmen, memotivasi pegawai, memperbaiki kinerja, memperbaiki proses pelatihan dan pengembangan, mengusahakan perbaikan dan pengembangan karir pegawai, membantu menahan pegawai terampil agar tidak pindah ke perusahaan lain, termasuk mendukung inisiatif kualitas total dan pelayanan pelanggan. Maka upaya-upaya untuk meningkatkan kinerja pegawai merupakan tantangan manajemen yang paling serius, karena keberhasilan untuk mencapai tujuan dan kelangsungan hidup perusahaan tergantung pada kualitas kinerja sumber daya manusia yang ada didalamnya.

CV. Lima Saudara Mandiri didirikan pada tanggal 17 Desember 2015 di Bandar Lampung, lahir dari pemikiran dan keinginan yang ideal untuk menjawab tantangan dan harapan di dunia usaha, baik bidang pengadaan barang, jasa perawatan dan perbaikan mesin maupun jasa konstruksi. Sebagai perusahaan swasta yang sedang berkembang, harus mampu bersaing dalam mendapatkan pekerjaan/proyek, baik dari perusahaan swasta maupun Badan Usaha Milik Negara (BUMN). Pegawai yang handal, loyal dan memiliki kinerja yang tinggi sangat diperlukan dalam pengelolaan perusahaan. Karena semakin banyak pegawai yang mempunyai kinerja tinggi, maka produktivitas perusahaan secara keseluruhan akan meningkat sehingga perusahaan akan dapat bertahan dalam persaingan global. Kinerja yang baik adalah kinerja optimal yang sesuai dengan standar organisasi dan mendukung tercapainya tujuan organisasi. Peningkatan kinerja pegawai akan membawa kemajuan bagi perusahaan untuk dapat bertahan dalam suatu persaingan bisnis di era globalisasi yang semakin kompetitif ini. Untuk mengetahui pengembangan karir yang diberikan oleh CV. Lima Saudara Mandiri Bandar Lampung terhadap pegawainya, maka pada penulis melakukan wawancara (interview) dengan Direktur dan beberapa pegawainya.

Hasil wawancara (interview) tersebut disimpulkan bahwa kesempatan mengembangkan karir dan kompetensi di CV. Lima Saudara Mandiri Bandar Lampung sangat lebar, dan setiap pegawai memiliki peluang dan kesempatan yang sama untuk dapat naik grade dan menduduki jabatan dimana pegawai yang berkompeten akan mendapat promosi jabatan. Namun hampir sebagian pegawai di perusahaan tersebut merasa kurang puas terhadap pengembangan diri dalam bentuk promosi jabatan, karena adanya perbedaan perlakuan pimpinan dalam penilaian masa kerja, disiplin kerja, kompetensi, dan kinerja pegawai. Selain itu, adanya ketidakjelasan sistem pengembangan karir pegawai dalam hal kriteria, serta tidak transparansinya proses pengembangan karir di CV. Lima Saudara Mandiri Bandar Lampung. Hal ini menimbulkan kecemburuan sosial dan dianggap sebagai sesuatu yang menganggu keadilan dan kesetaraan dalam pengembangan karir.

Penyesuaian ijazah tidak mempengaruhi terhadap peningkatan jenjang karir pegawai, kecuali pegawai 
tersebut memang diberikan kesempatan oleh CV. Lima Saudara Mandiri Bandar Lampung untuk menempuh pendidikan ke jenjang lebih tinggi. Berdasarkan uraian tersebut diatas, maka dilakukan penelitian (research) untuk mengetahui sejauh mana pengaruh pengembangan karir terhadap kinerja pegawai dengan judul "Pengaruh Pengembangan Karir Terhadap Kinerja Pegawai CV. Lima Saudara Mandiri Bandar Lampung".

\section{KERANGKA DASAR TEORI}

\section{Pengertian Manajemen Sumber Daya Manusia}

Menurut Desseler (2015:3), manajemen sumber daya manusia adalah proses untuk memperoleh, melatih, menilai, dan mengompensasi karyawan dan untuk mengurus relasi tenaga kerja, kesehatan dan keselamatan, serta halhal-hal yang berhubungan dengan keadilan.

\section{Pengembangan Karir}

Menurut Sunyoto (2012:164), pengembangan karir adalah peningkatanpeningkatan pribadi yang dilakukan seseorang untuk mencapai suatu rencana. Sedangkan menurut Marwansyah (2012:208), pengembangan karir adalah kegiatan-kegiatan pengembangan diri untuk ditempuh oleh seseorang untuk mewujudkan karir pribadinya.

\section{Pengertian Kinerja}

Menurut Wirawan (2009), kata kinerja berasal dari kata performance (Bahasa Inggris) yang sering diartikan dalam Bahasa Indonesia sebagai performa. Sedangkan menurut Mangkunegara (2001:67), kinerja adalah hasil kerja yang secara kualitas dan kuantitas yang telah dicapai oleh seorang karyawan atau pegawai dalam mengemban tugasnya sesuai dengan tanggung jawab yang telah diberikan kepadanya.

\section{Indikator Kinerja Pegawai}

Di setiap perusahaan selalu ada evaluasi kinerja, dimana setiap pegawai akan dinilai dalam beberapa periode tertentu. Penilaian tersebut dilakukan untuk melihat sejauh mana pegawai dapat bekerja dan memenuhi standar perusahaan sehingga kalau ada penyimpangan atau kesalahan bisa dilakukan perbaikan secepatnya. Untuk mengukur kinerja pegawai secara individual ada beberapa indikator yang digunakan. Menurut Robbins (2006:260), ada enam indikator, yaitu :

\section{a. Kualitas.}

Kualitas kerja diukur dari persepsi karyawan terhadap kualitas pekerjaan yang dihasilkan serta kesempurnaan tugas terhadap keterampilan dan kemampuan karyawan;

b. Kuantitas.

Merupakan jumlah yang dihasilkan dinyatakan dalam istilah seperti jumlah unit, jumlah siklus aktivitas yang diselesaikan;

c. Ketepatan Waktu.

Merupakan tingkat aktivitas diselesaikan pada awal waktu yang dinyatakan, dilihat dari sudut koordinasi dengan hasil output serta memaksimalkan waktu yang tersedia untuk aktivitas lain;

d. Efektivitas.

Merupakan tingkat penggunaan sumber daya organisasi (tenaga, uang, teknologi, bahan baku) dimaksimalkan dengan maksud menaikkan hasil dari setiap unit dalam penggunaan sumber daya;

e. Kemandirian.

Merupakan tingkat seorang karyawan yang nantinya akan dapat menjalankan tugas kerjanya;

\section{f. Komitmen Kerja.}

Merupakan suatu tingkat dimana karyawan mempunyai komitmen kerja dengan instansi dan tanggung jawab karyawan terhadap kantor. 


\section{METODE PENELITIAN}

\section{Jenis Penelitian}

Jenis penelitian yang digunakan adalah penelitian kuantitatif. Menurut Kasiram (2008:149) dalam bukunya Metodologi Penelitian Kualitatif dan Kuantitatif, penelitian kuantitatif adalah suatu proses menemukan pengetahuan yang menggunakan data berupa angka sebagai alat menganalisis keterangan mengenai apa yang ingin diketahui.

Cara pembahasan dalam penelitian ini menggunakan aplikasi program IBM SPSS Statistics Base (Statistical Package for the Social Sciences) Ver. 22

\section{Populasi dan sampling}

Populasi dalam penelitian ini adalah pegawai CV. Lima Saudara Mandiri Bandar Lampung. Sampel yang digunakan dalam penelitian ini adalah 62 pegawai yang diteliti dari beberapa Bagian/Divisi: Bagian Umum dan Administrasi (General and Administration Department) sebanyak 5 orang, Bagian Pemasaran

(Marketing Department) sebanyak 9 orang, Bagian Personalia (Human Resources Department) sebanyak 3 orang, dan Bagian Produksi (Production Department) sebanyak 45 orang.

\section{Definisi Operasional}

\begin{tabular}{|c|l|l|}
\hline Variabel & \multicolumn{1}{|c|}{ Sub Variabel } & \multicolumn{1}{|c|}{ Indikator } \\
\hline & $\begin{array}{l}\text { Prestasi kerja } \\
\text { (X.a) }\end{array}$ & $\begin{array}{l}\text { Prestasi kerja, hal } \\
\text { utama dalam } \\
\text { pengembangan } \\
\text { karir }\end{array}$ \\
\cline { 2 - 3 } $\begin{array}{c}\text { Pengembangan } \\
\text { Karir (X) }\end{array}$ & Exposure (X.b) & $\begin{array}{l}\text { Karyawan } \\
\text { memiliki } \\
\text { hubungan yang } \\
\text { baik dengan } \\
\text { atasan dan } \\
\text { teman sejawat } \\
\text { untuk }\end{array}$ \\
\hline
\end{tabular}

\begin{tabular}{|c|c|c|}
\hline & & $\begin{array}{l}\text { mendukung } \\
\text { pengembangan } \\
\text { karir }\end{array}$ \\
\hline & $\begin{array}{l}\text { Kesetiaan - } \\
\text { Organisasional } \\
\text { (X.c) }\end{array}$ & $\begin{array}{l}\text { Lamanya bekerja } \\
\text { tolak ukur dalam } \\
\text { pengembangan } \\
\text { karir }\end{array}$ \\
\hline & $\begin{array}{l}\text { Mentor dan } \\
\text { sponsor }(X . d)\end{array}$ & $\begin{array}{l}\text { Atasan } \\
\text { memberikan } \\
\text { promosi jabatan } \\
\text { adil dan tanpa } \\
\text { pilih kasih }\end{array}$ \\
\hline & $\begin{array}{l}\text { Kesempatan- } \\
\text { kesempatan } \\
\text { untuk tumbuh } \\
\text { (X.e) }\end{array}$ & $\begin{array}{l}\text { Kesempatan } \\
\text { mendapatkan } \\
\text { diklat dan } \\
\text { pelatihan kerja } \\
\text { peningkatan } \\
\text { kemampuan }\end{array}$ \\
\hline \multirow{5}{*}{ Kinerja $(Y)$} & Kualitas (Y.a) & $\begin{array}{l}\text { Menyelesaikan } \\
\text { pekerj } \\
\text { aan dengan } \\
\text { sebaik-baiknya } \\
\text { dan } \\
\text { meningkatkan } \\
\text { kinerja }\end{array}$ \\
\hline & Kuantitas (Y.b) & $\begin{array}{l}\text { Semaksimal } \\
\text { mungkin untuk } \\
\text { menyelesaikan } \\
\text { pekerjaan rutin } \\
\text { dengan cepat }\end{array}$ \\
\hline & $\begin{array}{l}\text { Ketepatan Waktu } \\
\text { (Y.c) }\end{array}$ & \begin{tabular}{lr}
\multicolumn{2}{l}{ Menyelesaikan } \\
pekerjaan & sesuai \\
waktu & yang \\
diberikan & \\
\end{tabular} \\
\hline & Efektifitas (Y.d) & $\begin{array}{lr}\text { Bekerja } & \text { cepat } \\
\text { dengan } & \text { hasil } \\
\text { yang memuaskan }\end{array}$ \\
\hline & $\begin{array}{l}\text { Kemandirian } \\
\text { (Y.e) }\end{array}$ & \begin{tabular}{lr}
\multicolumn{2}{l}{ Bertanggung } \\
jawab terhadap \\
semua resiko \\
pekerjaan
\end{tabular} \\
\hline
\end{tabular}

\section{HASIL PENELITIAN DAN PEMBAHASAN}

\section{Hasil Penelitian}

\section{Deskripsi Variabel Penelitian}

\section{Variabel Pengembangan Karir (X)}

Tabel Tanggapan responden terhadap Variabel Pengembangan Karir (X)

\begin{tabular}{|l|c|c|c|c|c|c|}
\hline $\begin{array}{c}\text { Tanggapa } \\
\text { n }\end{array}$ & $\begin{array}{c}\text { Sko } \\
\mathbf{r}\end{array}$ & X.a & X.b & X.c & X.d & X.e \\
\hline $\begin{array}{l}\text { Sangat } \\
\text { Tidak } \\
\text { Setuju } \\
\text { (STS) }\end{array}$ & 1 & $0 \%$ & $0 \%$ & $0 \%$ & $0 \%$ & $0 \%$ \\
\hline $\begin{array}{l}\text { Tidak } \\
\text { Setuju } \\
\text { (TS) }\end{array}$ & 2 & $0 \%$ & $0 \%$ & $0 \%$ & $\begin{array}{c}74,2 \\
\%\end{array}$ & $0 \%$ \\
\hline Netral (N) & 3 & $0 \%$ & $0 \%$ & $0 \%$ & $\begin{array}{c}19,4 \\
\%\end{array}$ & $0 \%$ \\
\hline Setuju (S) & 4 & $\begin{array}{c}87,1 \\
\%\end{array}$ & $\begin{array}{c}85,5 \\
\%\end{array}$ & $\begin{array}{c}42,9 \\
\%\end{array}$ & $\begin{array}{c}6,4 \% \\
5,4\end{array}$ \\
\hline Sangat & 5 & 12,9 & 14,5 & 57,1 & $0 \%$ & 46,8 \\
\hline
\end{tabular}




\begin{tabular}{|l|c|c|c|c|c|}
\hline $\begin{array}{l}\text { Setuju } \\
\text { (SS) }\end{array}$ & $\%$ & $\%$ & $\%$ & & $\%$ \\
\hline $\begin{array}{l}\text { Mean Skor Sub } \\
\text { Variabel }\end{array}$ & $\mathbf{4 , 1 2}$ & $\mathbf{4 , 1 4}$ & $\mathbf{4 , 5 6}$ & $\mathbf{2 , 1 6}$ & $\mathbf{4 , 4 7}$ \\
\hline $\begin{array}{l}\text { Mean Skor } \\
\text { Variabel }\end{array}$ & \multicolumn{5}{|c|}{$\mathbf{3 , 8 9}$} \\
\hline
\end{tabular}

Sumber: data diolah, 2019

Berdasarkan tabel diatas pada sub variabel prestasi kerja (X.a) menunjukan bahwa sebagian besar responden menyatakan Setuju $(87,1 \%)$ bahwa di CV. Lima Saudara Mandiri Bandar Lampung, prestasi kerja merupakan hal utama yang dipertimbangkan untuk pengembangan karir, diikuti yang menyatakan Sangat Setuju (12,9\%), dan tidak ada yang menyatakan netral, tidak setuju dan sangat tidak setuju, rata-rata skor sub variabel yang diperoleh 4.12 yang artinya responden menyatakan setuju terhadap sub variabel tersebut.

Tanggapan mengenai Exposure (X.b) menunjukkan bahwa sebagian besar responden menyatakan Setuju (85,5\%), bahwa exposure merupakan hal yang dipertimbangkan dalam pengembangan karir karena tanpa exposure pegawai yang berprestasi mungkin tidak akan mendapatkan sasaran karirnya. Kemudian diikuti yang menyatakan Sangat Setuju $(14,5 \%)$, dan tidak ada yang menyatakan netral, tidak setuju serta tidak ada yang menyatakan sangat tidak setuju. Rata-rata skor yang diperoleh 4.14 yang artinya responden menyatakan setuju terhadap sub variabel tersebut.

Tanggapan mengenai kesetiaan organisasional (X.c) menunjukkan bahwa sebagian besar responden pada penelitian ini menyatakan Sangat Setuju $(57,1 \%)$ yang artinya bahwa di CV. Lima Saudara Mandiri Bandar Lampung, kemajuan karir salah satunya tergantung pada masa kerja pegawai, diikuti tanggapan responden Setuju (42,9\%), tidak ada menyatakan netral, tidak setuju dan sangat tidak setuju. Rata-rata skor yang diperoleh adalah 4.56 yang artinya responden menyatakan sangat setuju terhadap sub variabel tersebut. 6
Tanggapan mengenai mentor dan sponsor (X.d) menunjukkan sebagian besar responden pada penelitian ini menyatakan Tidak Setuju $(74,2 \%)$ bahwa pegawai di CV. Lima Saudara Mandiri merasa belum puas masalah pengembangan karir dalam bentuk promosi jabatan terutama untuk kenaikan golongan. Diikuti tanggapan responden Netral $(19,4 \%)$, Setuju $(6,4 \%)$ dan tidak ada yang menyatakan sangat setuju. Rata-rata skor sub variabel yang diperoleh 2,28 yang artinya responden menyatakan tidak setuju terhadap sub variabel tersebut.

Tanggapan mengenai kesempatankesempatan untuk tumbuh (X.e) menunjukkan sebagian besar responden pada penelitian ini menyatakan Setuju $(53,2 \%)$ bahwa di CV. Lima Saudara Mandiri Bandar Lampung memberikan kesempatan kepada pegawai untuk mengikuti diklat guna meningkatkan kemampuan pegawai. Selanjutnya diikuti tanggapan responden Sangat Setuju (46,8\%), dan tidak ada yang menyatakan netral, tidak setuju dan sangat tidak setuju. Rata-rata skor sub variabel yang diperoleh 4,47 yang artinya responden menyatakan sangat setuju terhadap sub variabel tersebut.

Dari kelima sub variabel Pengembangan Karir (X) diperoleh ratarata skor variabel sebanyak 3,89 artinya responden menyatakan Setuju bahwa variabel Pengembangan Karir (X) di CV. Lima Saudara Mandiri Bandar Lampung sudah dilaksanakan dengan baik.

\section{Variabel Kinerja Karyawan (Y)}

Tabel Tanggapan responden terhadap Variabel Kinerja Karyawan

\begin{tabular}{|l|c|c|c|c|c|c|}
\hline $\begin{array}{l}\text { Tanggapa } \\
\text { n }\end{array}$ & $\begin{array}{c}\text { Sko } \\
\text { r }\end{array}$ & X.a & X.b & X.c & X.d & X.e \\
\hline $\begin{array}{l}\text { Sangat } \\
\text { Tidak } \\
\text { Setuju } \\
\text { (STS) }\end{array}$ & 1 & $0 \%$ & $0 \%$ & $0 \%$ & $0 \%$ & $0 \%$ \\
\hline $\begin{array}{l}\text { Tidak } \\
\text { Setuju } \\
\text { (TS) }\end{array}$ & 2 & $0 \%$ & $0 \%$ & $0 \%$ & $0 \%$ & $0 \%$ \\
\hline Netral (N) & 3 & $0 \%$ & $0 \%$ & $0 \%$ & $0 \%$ & $0 \%$ \\
\hline Setuju (S) & 4 & 96,7 & 96,7 & 96,7 & 96,7 & 90,3 \\
\hline
\end{tabular}




\begin{tabular}{|c|c|c|c|c|c|c|}
\hline & & $\%$ & $\%$ & $\%$ & $\%$ & $\%$ \\
\hline $\begin{array}{l}\text { Sangat } \\
\text { Setuju } \\
\text { (SS) }\end{array}$ & 5 & $3,3 \%$ & $3,3 \%$ & $3,3 \%$ & $3,3 \%$ & $9,7 \%$ \\
\hline \multicolumn{2}{|c|}{$\begin{array}{l}\text { Mean Skor Sub } \\
\text { Variabel }\end{array}$} & 4,13 & 4,13 & 4,13 & 4,13 & 4,07 \\
\hline \multicolumn{2}{|c|}{$\begin{array}{l}\text { Mean Skor } \\
\text { Variabel }\end{array}$} & \multicolumn{5}{|c|}{4,11} \\
\hline
\end{tabular}

Sumber: data diolah, 2019

Dari tabel diatas dapat dilihat bahwa jawaban responden terhadap variabel kinerja pegawai dari sub variabel kualitas (Y.a) menunjukkan bahwa mayoritas responden pada penelitian ini menyatakan Setuju $(96,7 \%)$ bahwa pegawai CV. Lima Saudara Mandiri Bandar Lampung selalu berusaha dengan sebaik- baiknya dan meningkatkan kinerja untuk perusahaan, kemudian diikuti jawaban Sangat Setuju $(3,3 \%)$, serta tidak ada yang menyatakan netral, tidak setuju, dan sangat tidak setuju. Rata-rata skor yang diperoleh adalah 4,13 artinya responden menyatakan setuju terhadap sub variabel tersebut.

Selanjutnya tanggapan responden mengenai kuantitas (Y.b) menunjukkan bahwa mayoritas responden pada penelitian ini menyatakan Setuju (96,7\%) bahwa pegawai CV. Lima Saudara Mandiri Bandar Lampung berusaha semaksimal mungkin mencari cara untuk menyelesaikan pekerjaan rutin dengan cepat, diikuti jawaban Sangat Setuju (3,3\%), serta tidak ada yang menyatakan netral, tidak setuju, dan sangat tidak setuju. Rata-rata skor yang diperoleh adalah 4,13 artinya responden menyatakan setuju terhadap sub variabel tersebut.

Tanggapan responden mengenai ketepatan waktu (Y.c) menunjukkan bahwa mayoritas responden pada penelitian ini menyatakan Setuju $(96,7 \%)$ bahwa pegawai CV. Lima Saudara Mandiri Bandar Lampung selalu dapat menyelesaikan pekerjaan sesuai dengan waktu yang ditetapkan oleh perusahaan, diikuti jawaban Sangat Setuju $(3,3 \%)$, serta tidak ada yang menyatakan netral, tidak setuju, dan sangat tidak setuju. Rata-rata skor yang diperoleh adalah 4,13 artinya responden menyatakan setuju terhadap sub variabel tersebut.

Tanggapan responden mengenai efektifitas (Y.d) menunjukkan bahwa mayoritas responden pada penelitian ini menyatakan Setuju $(96,7 \%)$ bahwa pegawai CV. Lima Saudara Mandiri Bandar Lampung mampu bekerja cepat dengan hasil yang memuaskan, diikuti jawaban Sangat Setuju (3,3\%), serta tidak ada yang menyatakan netral, tidak setuju, dan sangat tidak setuju. Ratarata skor yang diperoleh adalah 4,13 artinya responden menyatakan setuju terhadap sub variabel tersebut.

Tanggapan responden mengenai kemandirian (Y.e) menunjukkan bahwa mayoritas responden pada penelitian ini menyatakan Setuju $(90,3 \%)$ bahwa pegawai CV. Lima Saudara Mandiri Bandar Lampung bertanggung jawab terhadap semua pekerjaaan yang menjadi tanggung jawabnya, diikuti jawaban Sangat Setuju $(9,7 \%)$, serta tidak ada yang menyatakan netral, tidak setuju, dan sangat tidak setuju. Rata-rata skor yang diperoleh adalah 4,07 artinya responden menyatakan setuju terhadap sub variabel tersebut.

Dari kelima sub variabel kinerja karyawan (Y) secara keseluruhan diperoleh rata-rata skor variabel sebanyak 4,11 artinya responden menyatakan setuju terhadap variabel kinerja karyawan (Y).

\section{Pembahasan}

\section{Pengembangan Karir Pegawai CV. Lima Saudara Mandiri Bandar Lampung}

Setelah melakukan penelitian dengan melakukan penyebaran kuesioner kepada pegawai CV. Lima Saudara Mandiri Bandar Lampung, penulis menemukan fakta pada sub variabel pengembangan karir, yaitu:

a. Sub Variabel Prestasi Kerja (X.a)

Diketahui bahwa untuk pegawai yang berprestasi dan berkompeten kenaikan 
grade dapat dilakukan setiap 6 (enam) bulan sekali setiap kenaikan 1 (satu) Grade, dengan ketentuan sanggup mempertahankan talenta luar biasa/sangat potensial/sangat optimal, serta kenaikan Grade tersebut dibatasi maksimal 2 (dua) Grade diatas Grade sebelum mengikuti Uji Portofolio Kompetensi, dan hanya berlaku satu kali sepanjang riwayat jabatan di perusahaan tersebut. Hal ini didukung dengan mayoritas pegawai menyatakan setuju sebanyak $87,1 \%$ terhadap pernyataan prestasi kerja merupakan hal utama yang dipertimbangkan untuk pengembangan karir.

b. Sub Variabel Exposure (X.b)

Pegawai CV. Lima Saudara Mandiri Bandar Lampung memiliki hubungan yang baik dengan atasan dan rekan sejawat untuk mendukung pengembangan karir, hal ini didukung dengan mayoritas jawaban responden yang menyatakan setuju sebanyak $85,5 \%$. Kemajuan karir juga ditentukan oleh exposure karena tanpa exposure, pegawai yang berprestasi mungkin tidak memperoleh kesempatan untuk mencapai sasaran karirnya, dalam hal ini penulis menyarankan hendaknya perlu dikembangkan lagi intensitas komunikasi interaktif dalam rangka meningkatkan tanggung jawab agar mampu mendorong pegawai potensial untuk meningkatkan kinerjanya melalui inovasi dan inisiatif terhadap kemajuan perusahaan CV. Lima Saudara Mandiri Bandar Lampung.

\section{c. Sub Variabel \\ Organisasional (X.c)}

Kesetiaan

Sub variabel ini merupakan dedikasi jangka panjang terhadap perusahaan, dimana kemajuan karir salah satunya tergantung pada kesetiaan organisasional. Sebagai penghargaan atas masa kerja pegawai, CV. Lima Saudara Mandiri Bandar Lampung memberikan kebijakan mengenai pembinaan skala Grade berupa pemindahan 1 (satu) Skala Grade ke skala di samping kanan, setiap 1 (satu) tahun sekali. Persyaratan kenaikan level kompetensi adalah lulus Uji Portofolio Kompetensi:

1. Rekomendasi dari Bagian/Divisi atau atasan langsung;

2. Tidak sedang menjalani sanksi/hukuman disiplin;

3. Memenuhi persyaratan kriteria talenta yang diatur dalam petunjuk pelaksanaan/peraturan perusahaan;

4. Memenuhi persyaratan kompetensi yang diatur dalam petunjuk pelaksanaan/peraturan perusahaan.

d. Sub Variabel Mentor dan Sponsor (X.d)

Dalam kegiatan pengembangan karir seorang mentor dan sponsor dalam hal ini atasan langsung sangat berperan penting, karena dengan adanya sponsor atau promosi maka dapat menciptakan kesempatankesempatan pengembangan karir bagi seorang pegawai.

Berdasarkan hasil penelitian yang penulis lakukan dengan melakukan penyebaran kuesioner kepada pegawai CV. Lima Saudara Mandiri Bandar Lampung, mayoritas jawaban responden terhadap pernyataan Direktur CV. Lima Saudara Mandiri Bandar Lampung memberikan kesempatan yang adil dan tanpa pilih kasih dalam pengembangan karir, diketahui mayoritas jawaban responden menyatakan tidak setuju sebanyak $74,2 \%$, karena sebagian karyawan merasa belum puas masalah pengembangan karir dalam bentuk promosi jabatan terutama untuk kenaikan golongan karena masih banyak karyawan yang tingkat pendidikannya Sekolah Lanjutan Atas / Diploma sehingga adanya perbedaan perlakuan Pimpinan terhadap karyawan yang memiliki pendidikan Sekolah Lanjutan Atas / Diploma dan Sarjana. 
Adapun saran dari penulis, sebaiknya Direktur sebagai pimpinan harus berlaku adil tanpa membeda-bedakan pegawai dalam memberikan sponsor atau promosi jabatan kepada pegawai yang potensial, inisiatif, disiplin, dan menyediakan posisi jabatan yang lebih baik bagi pegawai yang mampu meraih kinerja yang optimal.

e. Sub Variabel Kesempatankesempatan untuk tumbuh (X.e)

Untuk meningkatkan kemampuan memberikan kesempatan kepada pegawai untuk mengambil kuliah sore atau malam hari guna meningkatkan kemampuan pegawai.

Berdasarkan hasil penelitian yang penulis lakukan dengan melakukan penyebaran kuesioner kepada pegawai CV. Lima Saudara Mandiri Bandar Lampung, mayoritas jawaban responden menyatakan setuju sebanyak 53,2\%. Hal ini menunjukkan bahwa pegawai CV. Lima Saudara Mandiri Bandar Lampung merasa puas diberikannya kesempatan mengikuti diklat dan pelatihan untuk meningkatkan kemampuan pegawai.

Pengaruh pengembangan karir terhadap kinerja pegawai CV. Lima Saudara Mandiri Bandar Lampung

Hasil analisis uji "t" menunjukkan bahwa pengembangan karir mempunyai pengaruh terhadap kinerja pegawai $\mathrm{CV}$. Lima Saudara Mandiri Bandar Lampung.

Penelitian ini sejalan dengan teori Handoko yang menyatakan bahwa pengembangan karir dipengaruhi oleh beberapa indikator pengembangan karir individu yang mencakup prestasi kerja, exposure, kesetiaan organisasional, mentor dan sponsor dan kesempatan-kesempatan untuk tumbuh.

Fakta pengaruh pengembangan karir terhadap kinerja pegawai CV. Lima Saudara Mandiri Bandar Lampung dapat dilihat mayoritas jawaban responden terhadap pernyataan mengenai pengembangan karir pegawai yang menyatakan setuju bahwa pengembangan karir pegawai di CV. Lima Saudara Mandiri Bandar Lampung sudah dilaksanakan dengan baik. Kesempatan pengembangan karir di perusahaan CV. Lima Saudara Mandiri Bandar Lampung sangat terbuka dimana setiap pegawai memiliki kesempatan yang sama untuk dapat naik Grade dan mendapatkan promosi jabatan bagi pegawai yang berkompeten. Kriteria kenaikan Grade dilihat dari penilaian kompetensi, disiplin kerja, masa kerja, dan kinerja yang memuaskan. Sedangkan kendala kenaikan Grade antara lain: tidak ada gagasan atau inisiatif untuk memajukan perusahaan, tidak disiplin, kurangnya promosi, dan faktor fisik.

Permasalahan yang penulis temukan adalah sebagian pegawai merasa kurang puas mengenai pengembangan karir dalam bentuk promosi jabatan terutama kenaikan Grade karena adanya perbedaan perlakuan dari Direktur terhadap pegawai yang mempunyai ijazah Sekolah Lanjutan Atas/Diploma dan Sarjana sehingga menimbulkan kecemburuan sosial dan dianggap sebagai sesuatu yang menganggu keadilan dan kesetaraan dalam kesempatan pelaksanaan maupun pengembangan karir di lingkungan perusahaan tersebut.

\section{PENUTUP}

Berdasarkan hasil analisis yang telah dilakukan sebagaimana dijelaskan tersebut maka dapat diperoleh kesimpulan bahwa pengembangan karir berpengaruh terhadap kinerja pegawai. Hal ini menunjukkan bahwa kebijakan pengembangan karir yang diterapkan oleh CV. Lima Saudara Mandiri Bandar Lampung mempengaruhi tingkat kinerja pegawai yang terlihat dari karakteristik responden berdasarkan jawaban atas daftar pertanyaan dari beberapa sub variabel prestasi kerja, exposure, kesetiaan organisasional, 
mentor dan sponsor, dan kesempatankesempatan untuk tumbuh. Hanya saja ada permasalahan di pengembangan karir terutama pada variabel mentor dan sponsor karena sebagian pegawai merasa kurang puas mengenai pengembangan karir dalam bentuk promosi jabatan terutama kenaikan Grade karena adanya perbedaan perlakuan dari Direktur terhadap pegawai yang memiliki ijazah Sekolah Lanjutan Atas/Diploma dan Sarjana sehingga menimbulkan kecemburuan sosial.

Direktur CV. Lima Saudara Mandiri Bandar Lampung hendaknya berlaku adil tanpa diskriminasi dalam memberikan sponsor dan promosi kepada pegawai yang disiplin, inisiatif, dan potensial. Selanjutnya ia juga harus menyediakan posisi yang lebih baik bagi pegawai yang mampu meraih kinerja yang optimal.

\section{DAFTAR PUSTAKA}

Danang, Sunyoto. 2012, Manajemen Sumber Daya Manusia. Jakarta: PT. Buku Seru.

Dessler, Gary. 2015, Manajemen Sumber Daya Manusia, Jakarta: Salemba Empat.
Hasibuan, Malayu. 2013, Manajemen Sumber Daya Manusia, Jakarta: Bumi Aksara.

Kasiram, Mohammad. 2008, Metodologi Penelitian Kuantitatif-Kualitatif, Malang: UIN Malang Press.

Mangkunegara, Anwar Prabu. 2001, Manajemen Sumber Daya Perusahaan, Bandung: PT. Remaja Rosdakarya.

Marwansyah. 2012, Manajemen Sumber Daya Manusia, Bandung: Alfabeta.

Notoatmodjo, Soekidjo. 2009, Pengembangan Sumber Daya Manusia, Jakarta: Rineka Cipta.

Robbins, Stephen P. 2006, Perilaku Organisasi (alih bahasa Drs.Benjamin Molan), Edisi Bahasa Indonesia, Klaten: PT. Intan Sejati.

Sugiyono. 2014, Metode Penelitian Bisnis, Bandung: Alfabeta.

T. Hari, Handoko. 2015, Manajemen Personalia dan Sumber Daya Manusia, Edisi ke-2. Yogyakarta: BPFE

Wirawan. 2009, Evaluasi Kinerja Sumber Daya Manusia, Jakarta: Salemba Empat. 